\title{
The Factors Affecting Food Delivery Application Users Shopping Routine Behavior during the Covid-19 Pandemic
}

\author{
Sari Lestari Zainal Ridho ${ }^{1, *}$ Habsah Binti Haji Mohamad Sabli ${ }^{2}$ Kartini Binti Che \\ Ibrahim $^{2}$, Hadi Jauhari ${ }^{1}$ Detmuliati Alditia ${ }^{1}$ Alfitriani Alfitriani ${ }^{1}$ Putri Anggita \\ Prameswari Pracena ${ }^{1}$
}

\author{
${ }^{1}$ Politeknik Negeri Sriwijaya, Palembang, Sumatera Selatan, Indonesia \\ ${ }^{2}$ Politeknik Mukah, Mukah, Sarawak, Malaysia \\ *Corresponding author. Email: sarilestari@poslri.ac.id
}

\begin{abstract}
The purpose of this study is to evaluate the influence of variables that affect the shopping routines of food delivery application users during the Covid-19 pandemic. Food Delivery Application refers to application based deliver services that make the customer easier consume food from the restaurant. Data collection was carried out in the third quarter of 2021 and this research obtained 117 respondents who met the criteria required for this study, using the purposive sampling technique. The data collected were analyzed using the technique of Partial Least Squares Structural Equation Modeling. Based on the results of data processing, it shows that Price Advantage, Trust, Interface Issues are significant and have a positive effect on the Shopping Routines of Food Delivery Application users. The implication of these findings is Food Delivery Application providers should improve and or maintain the business policy regarding the price, trust and interface of the application. For instance, by giving more price advantages, increasing the service receiver trust and improving interface of the applications.
\end{abstract}

Keywords: Restaurant, Food Delivery Application, Shopping Routine, Covid-19.

\section{INTRODUCTION}

Restaurant is providing food and beverage services business, which is an important contributor in the tourism industry [1]-[3]. Food purchasing process at the restaurant can be done directly on the spot or can use the food delivery application. Food Delivery Application refers to application based deliver services that make the customer easier consume food from the restaurant. During the Covid-19 pandemic, the use of food delivery application has increased. Based on data from the socio demographic survey of theCovid-19 pandemic impact results, conducted by Statistic Indonesia in 2020[4], 9 out of 10 respondent carry out online shopping activities. Furthermore, the survey also provides information that there is an increase in food shopping activities.

The increase in the shopping routine of food delivery application users during the Covid-19 pandemic was caused by various rationale or reason. The rationale behind a behavior can be a possible reason for and a possible reason against [5]. Based on previous research, price advantage and trust are the possible reason for doing shopping routine, while interface is a reason against to [6]. The increase in the routine shopping for food using the delivery application, in one side creates positive conditions in restoring the economic disruption caused by Covid-19, on the other side, it also raises concerns over the environmental impacts of tourism that may occur, namely over ordering and food waste [6], hence based on previous research, other factors that are come to a concern, affect the shopping routine of food delivery users application is morality or moral norm [6][7][8][9]. Moral Norm represent the feeling of guilt that food delivery application users have if the food they ordered was not consumed and wasted [7]; interface issues related to the food delivery application functionality [10][11]; Trust is strong belief in reliability, safety, correctness, strength capability[11]; price 
advantages is competitive advantage in terms of price obtained by consumer of service receiver [12]; and shopping routine is the tendency of consumer to buy more than food needed, which creates the possibility of food waste [6][13].

Considering the possible impact of the increasing shopping routine behavior during the Covid-19 pandemic and the existence of various association between variables according to previous research, become a reason to carry out this research, and the purpose of this research is to evaluate the factors that affect the shopping routines of food delivery application users during the Covid-19 pandemic. This study examines this research question: are there any influences of price advantages, trust, interfaces, and moral norms on shopping routines during Covid-19 pandemic?.

\section{METHODOLOGY}

This study uses a quantitative descriptive method in testing the relationship between variables, using the Partial Least Square-Structural Equation Modeling (PLSSEM) technique. The reason for using SEM is SEM is an analytical technique to confirm further in order to determine whether a particular model is valid or not. The evaluation of PLS-SEM model consist of 2 evaluations, namely by evaluating the model (evaluating the outer model) and evaluating the structural model (evaluating the inner model). The evaluation of outer model includes the value of outer loading, average variance extracted (AVE), and composite reliability (CR), and the evaluation of inner model includes the value of path coefficients, and R-squre (R2) [14]-[16].

The population of this study were users of the food delivery application in Palembang, the population is unknown, since there were limitations in terms of time, hence for a research, refer to statistical requirement, the appropriate sample size in the study can be between 30 to 500[17]. In this study, the sample size used was 117 respondents, which was successfully collected through efforts to distribute as many questionnaires as possible during the Covid-19 pandemic, the third quarter of 2021.

\section{RESULT AND DISCUSSION}

\subsection{Descriptive Statistics}

Output Frequency Distribution Table of Frequency Table for gender, age and frequency of Food Delivery Applications users for the research framework or model is shown in this section. From the data processing, the frequency distribution table of the respondents demographic variables is generated as follows:
Table 1 Gender

\begin{tabular}{lrr}
\hline Gender & Frequency & Percentage \\
\hline Male & 29 & 24,8 \\
\hline Female & 88 & 75,2 \\
\hline Total & 117 & 100,0 \\
\hline
\end{tabular}

Source: Data Processing, 2021

Regarding the gender of the respondents, based on the results of the observation it is described that there are 88 female respondents $(75,2 \%)$, and the remaining 29 respondents are male. it can be concluded that almost three quarters of the respondents are women.

Table 2. Age

\begin{tabular}{lrr}
\hline Age & Frequency & Percentage \\
\hline 18 & 23 & 19,7 \\
\hline 19 & 38 & 32,5 \\
\hline 20 & 21 & 17,9 \\
\hline 22 & 7 & 6,0 \\
\hline 23 & 12 & 10,3 \\
\hline 24 & 6 & 5,1 \\
\hline 25 & 3 & 2,6 \\
\hline 29 & 1 & 0,9 \\
\hline 30 & 2 & 1,7 \\
\hline 32 & 1 & 0,9 \\
\hline 33 & 1 & 0,9 \\
\hline 54 & 1 & 0,9 \\
\hline Total & 1 & 0,9 \\
\hline Source· Data Processing 2021 & 100,0 \\
\hline
\end{tabular}

In term of respondent's age category, it was concluded that the age of the respondent spread out following a normal distribution that skewed to the right with ages between 18 and 54. The most respondents $(32 \%)$ were in the age of 19 years old.

Table 3. Use Frequency

\begin{tabular}{crr}
\hline Use Frequency & \multicolumn{1}{c}{ Frequency } & Percentage \\
\hline 1 time & 0 & 0,0 \\
\hline 2 times & 15 & 12,8 \\
\hline 3 times & 16 & 13,7 \\
\hline More than 3 times & 86 & 73,5 \\
\hline Total & 117 & 100,0 \\
\hline
\end{tabular}

Source: Data Processing, 2021

The using frequency of food delivery application by majority of respondents, as many as 86 respondents $(73,5 \%)$, 


\subsection{Uji Validitas dan Reliabilitas}

Validity testing was conducted to determine the correlation between each question item (indicator) and the total score of the question (factor). The indicator is said to be valid when the correlation $(r)>0.50$. In addition to testing reliability, the reliability coefficient used is Cronbach's Alpha. Cronbach's Alpha is a reliability coefficient calculated by the Alpha formula made by Cronbach. This test was conducted to determine the reliability (level of confidence) between the question items (all indicators) to the total score of all (factors). All indicators are said to be reliable when Cronbach's Alpha Value $>0.60$. From the output, it is found that the correlation between the Research Variables and their respective indicators is given in the following table.

Table 4. The results of the validity and reliability testing of the constructs between the researches variables and their indicators

\begin{tabular}{|c|c|c|c|}
\hline $\begin{array}{l}\text { Research } \\
\text { Variables }\end{array}$ & Indicator & correlation & $\begin{array}{l}\text { Cronbach's } \\
\text { Alpha }\end{array}$ \\
\hline \multirow{3}{*}{$\begin{array}{l}\text { Price } \\
\text { Advantage } \\
\text { (PA) }\end{array}$} & PA1 & 0,756 & \multirow[t]{3}{*}{$\alpha=0,756$} \\
\hline & PA2 & 0,847 & \\
\hline & PA3 & 0,859 & \\
\hline \multirow{3}{*}{$\begin{array}{l}\text { Trust } \\
\text { (TR) }\end{array}$} & TR1 & 0,876 & \multirow[t]{3}{*}{$\alpha=0,816$} \\
\hline & TR2 & 0,901 & \\
\hline & TR3 & 0,792 & \\
\hline \multirow{3}{*}{$\begin{array}{l}\text { Interface } \\
\text { Issues } \\
\text { (IF) }\end{array}$} & IF1 & 0,828 & \multirow[t]{3}{*}{$\alpha=0,766$} \\
\hline & IF2 & 0,816 & \\
\hline & IF3 & 0,841 & \\
\hline \multirow{3}{*}{$\begin{array}{l}\text { Norma } \\
\text { Moral } \\
(\mathrm{NM})\end{array}$} & NM1 & 0,941 & \multirow[t]{3}{*}{$\alpha=0,934$} \\
\hline & NM2 & 0,964 & \\
\hline & NM3 & 0,922 & \\
\hline \multirow{2}{*}{$\begin{array}{l}\text { Shopping } \\
\text { Routine } \\
\text { (SR) }\end{array}$} & SR1 & 0,938 & \multirow[t]{2}{*}{$\alpha=0,771$} \\
\hline & SR2 & 0,879 & \\
\hline
\end{tabular}

Source: Data Processing, 2021

From these results, the correlation coefficient of all indicators is greater than 0.50 , hence the validity test can be concluded that all indicators are said to be valid (accurate). In addition, all indicators have a correlation greater than 0.70 , its mean all indicators in this case can be said to be ideal. In addition, Cronbach's alpha values for Price Advantage (PA), Trust (TR), Interface Issues (IF), Moral Norms (MN), and Shopping Routine (SR) were $0.756,0.816,0.766,0.934$, and 0.771 respectively. Hence this reliability test can be concluded that all indicators are said to be reliable (trustworthy). Thus, testing the validity and reliability of the constructs of all indicators is concluded to be valid and reliable.

\subsection{Goodness of Fit}

Table 5. Overall Goodness of Fit for Final SEM

\begin{tabular}{|c|c|c|c|}
\hline $\begin{array}{l}\text { Goodness } \\
\text { of Fit }\end{array}$ & $\underset{\mathbf{t}}{\text { Resul }}$ & $\begin{array}{c}\text { Model } \\
\text { Requirement }\end{array}$ & $\begin{array}{c}\text { Testing } \\
\text { Decisio } \\
\text { n }\end{array}$ \\
\hline RMSEA & 0,079 & $\begin{array}{c}\text { RMSEA }<0,08 \\
\text { adalah good fit } \\
\text { RMSEA }<0,05 \\
\text { adalah close fit }\end{array}$ & good fit \\
\hline GFI & 0,887 & $\begin{array}{c}\text { GFI } \geq 0,90 \text { adalah } \\
\text { good fit } \\
0,80 \leq \mathrm{GFI} \leq 0,90 \\
\text { adalah marginal fit }\end{array}$ & $\begin{array}{c}\text { margina } \\
l \text { fit }\end{array}$ \\
\hline AGFI & 0,828 & $\begin{array}{c}0 \leq \mathrm{AGFI} \leq 1 \\
\text { PGFI semakin } \\
\text { besar, semakin } \\
\text { baik. }\end{array}$ & good fit \\
\hline CFI & 0,939 & $\begin{array}{c}\text { CFI }>0,90 \text { adalah } \\
\text { good fit } \\
0,80 \leq \mathrm{CFI} \leq 0,90 \\
\text { adalah marginal fit }\end{array}$ & good fit \\
\hline TLI & 0,919 & $\begin{array}{c}\text { TLI }>0,90 \text { adalah } \\
\text { good fit } \\
0,80 \leq \mathrm{TLI} \leq 0,90 \\
\text { adalah marginal fit }\end{array}$ & good fit \\
\hline CMIN/DF & 1,729 & $\begin{array}{c}\text { CMIN/DF }<2,00 \\
\text { adalah good fit }\end{array}$ & good fit \\
\hline
\end{tabular}

Source: Data Processing, 2021

From the overall suitability test of the model, all the test results that show the model are of good value, so it can be concluded that the SEM model is good. Table 5 shows that the factor loading, VE, CR, and Cronbach's Alpha values are very satisfactory for the modified SEM model. All factor loadings are still above the cut-off value (0.50). The reliability obtained shows good results because all variance extracted (VE) values are greater than 0.50 , construct reliability (CR) is above 0.70 , and Cronbach's Alpha is above 0.60 (cut-off values). Table 5 provides a summary of the score information from factor loading, VE, CR, and Cronbach's Alpha for the modified SEM model. This test was held to test discriminant validity, with good results on CR. Table 6 shows the factor loading, CR, and Cronbach's alpha values for construct investigations 
Table 6. The Validity and Reliability Measurements for all Constructs

\begin{tabular}{lllll}
\hline $\begin{array}{l}\text { Item } \\
\text { Description }\end{array}$ & $\begin{array}{l}\text { Factor } \\
\text { Loading }\end{array}$ & VE & CR & \multicolumn{2}{c}{$\begin{array}{l}\text { Cronbach's } \\
\text { Alpha }\end{array}$} \\
\hline PA1 & 0.557 & 0.548 & 0.779 & 0.756 \\
PA2 & 0.752 & & & \\
PA3 & 0.876 & & & 0.819 \\
\hline TR1 & 0.832 & 0.617 & 0.826 & \\
TR2 & 0.869 & & & \\
TR3 & 0.635 & & & 0.766 \\
\hline IF1 & 0.802 & 0.537 & 0.776 & \\
IF2 & 0.692 & & & 0.934 \\
IF3 & 0.699 & & & \\
\hline NM1 & 0.883 & 0.833 & 0.937 & \\
NM2 & 0.982 & & & 0.771 \\
NM3 & 0.869 & & & \\
\hline SR1 & 0.778 & 0.636 & 0.778 & \\
SR3 & 0.817 & & & \\
\hline Source: Data Processing, 2021 & &
\end{tabular}

\subsection{Interpretation of Path Coefficients in SEM}

The result of the coefficient of determination ( $\mathrm{R}-$ Square, R2) is 0.498; meaning that the diversity of the SR constructs that can be explained by the PA, TR, IF, and $\mathrm{MN}$ constructs together is $49.8 \%$ and the remaining $50.2 \%$ is explained by other constructs that have not been included in the SEM model. The results of the hypothesis shown in Table 7 show the results of hypothesis testing. Table 7 shows the results of hypothesis testing in the direct relationship of several constructs. Of the 3 hypotheses formulated, all hypotheses are significant with $\mathrm{p}$-value $<0.05$. In addition, the largest estimate $(0.708)$ is given between IF and SR

Table 7. The Relationship Path among the Constructs.

\begin{tabular}{lllll}
\hline $\begin{array}{l}\text { Hypothesized } \\
\text { Paths }\end{array}$ & Estimate & C.R. & P & Result \\
\hline H1: PA ->SR & 0.502 & 2.350 & $0.019^{* *}$ & Siqnificant \\
\hline H2: TR ->SR & 0.357 & 2.254 & $0.024^{* *}$ & Siqnificant \\
\hline H3: IF ->SR & 0.708 & 4.975 & $<0.001^{* * *}$ & Siqnificant \\
\hline H4: MN ->SR & 0.084 & 0.580 & 0.562 & $\begin{array}{l}\text { Not } \\
\text { Siqnificant }\end{array}$ \\
\hline
\end{tabular}

Note: $* * *, * *$, and * denote the two-tail statistical significance at $1 \%, 5 \%$, and $10 \%$ respectivel

Source: Data Processing, 2021

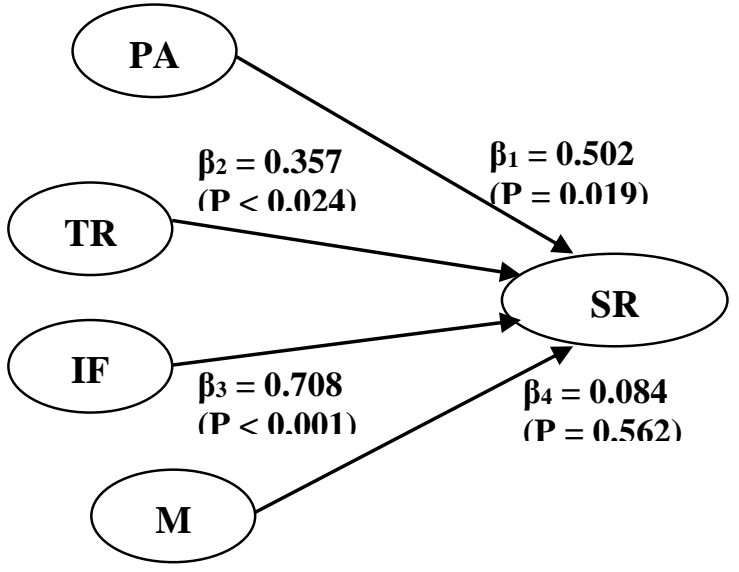

Figure 1. Path Coefficient

$\mathrm{SR}=0.502 \mathrm{PA}+0.357 \mathrm{TR}+0.708 \mathrm{IF}+0.084 \mathrm{MN}+\mathrm{e}(1)$

In the structural equation, the test obtained the following results and conclusions:

It is obtained a direct effect of Price Advantage (PA) which is significant on Shopping Routine (SR) of 0.502. The higher the Price Advantage value, the higher the Shopping Routine value; conversely, the lower the Price Advantage value, the lower the Shopping Routine value. it is also obtained a direct effect of Trust (PA) which is significant on Shopping Routine (SR) of 0.357. The higher the Trust value, the higher the Shopping Routine value; conversely, the lower the Trust value, the lower the Shopping Routine value.

Furthermore, it is obtained that the direct effect of Interface Issues (IF) which is significant on Shopping Routine (SR) is 0.708 . The higher the Interface Issues value, the higher the Shopping Routine value; conversely, the lower the Interface Issues value, the lower the Shopping Routine value. There is no significant direct effect of Moral Norms (NM) on Shopping Routine (SR). The higher/lower the Moral Norm value, it does not affect the Shopping Routine value.

The results found in this study support previous research that price advantage and trust have a positive and significant effect on routine shopping for more food than needed according to the results of Sharma et.al's research. [6]. Likewise, for interface problems, the results have a positive and significant effect on shopping routines, these results indicate that the current interface is no longer an obstacle for application users, this phenomenon can be explained by the social changes that occur, where today's society is a smart society that interacts intense with technology. Meanwhile, morality or moral norms are contrary to previous research where the moral attitude towards perceived supervision is one of the determinants of shopping routines [8], [9] 


\section{CONCLUSION}

Previously, as has been stated, the purpose of this study is to evaluate the effect of variables that affect the shopping routine behavior of food delivery application users during the Covid-19 pandemic. Based on the results obtained, it can be concluded that three of the four independent variables are significant and in accordance with the theory, namely Price Advantage, Trust, significant and positive influence and Interface Issues on the Shopping Routines of Food Delivery Application users. Meanwhile, the moral norm variable (indicators of guilt on others who do not have enough food, guilt about the environment, and bad feelings when throwing away the purchased food) has no effect on the tendency of consumers to buy more food than the needed food. allows for the creation of food waste. The implication of this finding is that a special strategy is needed to encourage restaurant service users through food delivery applications, because the impact of shopping routines without moral control can lead to negative consequences for the environment and the people who live in it. Furthermore, the limitations of this research can be used as an agenda for future work, such as the addition of different variables, the use of different analytical techniques and different respondent areas and a larger number of samples.

\section{AUTHORS' CONTRIBUTIONS}

Sari Lestari Zainal Ridho design the research, Habsah Binti Haji Mohamad Sabli, and Kartini Binti Che Ibrahim supervised the research project, Hadi Jauhari helped supervised the research project, Alditia Detmuliati and Alfitriani collected the data, Anggita Prameswari Pracena Putri discussed the introduction of research. All authors provided feedback and helped shape the research, analysis and manuscript.

\section{ACKNOWLEDGMENTS}

We acknowledged and also appreciate the institution of Politeknik Negeri Sriwijaya, Palembang, Sumatera Selatan, Indonesia and Politeknik Mukah Sawarak, Malaysia for the support and provision of enabling working environment that made this research conducted.

\section{REFERENCES}

[1] B. Budisetyorini, "Analisis Penyerapan Tenaga Kerja Sektor Pariwisata (Sektor Perdagangan, Hotel dan Restoran) di Kota Batu," J. Ekon. Pembang., vol. 11, no. 02, pp. 12-26, 2013.

[2] N. D. Anjasmara, Kadek Deny Setiawina, "Pengaruh Daya Tarik Wisata, Hotel, Restoran, Biro Perjalanan terhadap Penyerapan Tenaga Kerja dan Pendapatan Perkapita," Bul. Stud. Ekon., vol. 24, no. 2, pp. 234-251, 2019.
[3] A. Agoes and N. F. Pasaribu, "Kajian Pustaka Mengenai Restaurant Atmosphere," Binus Bus. Rev., vol. 6, no. 1, pp. 110-116, 2015, doi: 10.21512/bbr.v6i1.994.

[4] T. Putranto, Windhiarso Ponco Adi;Larasaty, Putri;Kurniasih, Anna; Pratiwi, Aprilia Ira; Saputri, Valent Gigih; Meilianingsih, Hasil Survei Sosial Demografi Dampak Covid-19 2020. Badan Pusat Statistik, 2020.

[5] A. K. Sahu, R. K. Padhy, and A. Dhir, "Envisioning the future of behavioral decision-making: A systematic literature review of behavioral reasoning theory," Australas. Mark. J., vol. 28, no. 4, pp. 145159, 2020, doi: 10.1016/j.ausmj.2020.05.001.

[6] R. Sharma, A. Dhir, S. Talwar, and P. Kaur, "Overordering and food waste: The use of food delivery apps during a pandemic,” Int. J. Hosp. Manag., vol. 96, no. April, p. 102977, 2021, doi: 10.1016/j.ijhm.2021.102977.

[7] Y. Yuan, H. Nomura, Y. Takahashi, and M. Yabe, "Model of Chinese household kitchen waste separation behavior: A case study in Beijing City," Sustain., vol. 8, no. 10, pp. 1-15, 2016, doi: 10.3390/su8101083.

[8] B. Richter and W. Bokelmann, "The significant of avoiding household food waste - A means - end chain approach," Waste Manag., vol. 74, pp. 34-42, 2018, doi: https://doi.org/10.1016/j.wasman.2017.12.012.

[9] V. Stefan, E. van Herrpen, A. A. Tudoran, and L. Lahteenmaki, "Avoiding food waste by Romanian consumers: The importance of planning and shopping routines," Food Qual. Prefer., vol. 28, no. 1, pp. 375-381, 2013, doi: https://doi.org/10.1016/j.foodqual.2012.11.001.

[10] S. Talwar, A. Dhir, V. Scuotto, and P. Kaur, "Barriers and paradoxical recommendation behaviour in online to offline $(\mathrm{O} 2 \mathrm{O})$ services. A convergent mixed-method study," J. Bus. Res., vol. 131, no. April, pp. 25-39, 2021, doi: 10.1016/j.jbusres.2021.03.049.

[11] P. Kaur, A. Dhir, S. Talwar, and K. Ghuman, "The value proposition of food delivery apps from the perspective of theory of consumption value," Int. J. Contemp. Hosp. Manag., vol. 33, no. 4, pp. 11291159, 2020, doi: 10.1108/IJCHM-05-2020-0477.

[12] S. Talwar, A. Dhir, P. Kaur, and M. Mäntymäki, "Why do people purchase from online travel agencies (OTAs)? A consumption values perspective," Int. J. Hosp. Manag., vol. 88, no. 
February, p. 102534, 2020, doi: 10.1016/j.jhm.2020.102534.

[13] Ö. C. Niyaz and N. Demirba, "Determining the food waste behaviour of consumers in Northwest Turkey: A cross-sectional analysis," New Medit, vol. 19, no. 3, pp. 129-142, 2020, doi: 10.30682/nm2003i.

[14] P. L. Mokhtarian and D. T. Ory, "Structural Equations Models," Int. Encycl. Hum. Geogr., pp. 10-17, 2009, doi: 10.1016/B978-0080449104.00541-1.
[15] H. Latan and I. Ghozali, Partial Least Square: Konsep, Teknik dan Aplikasi Menggunakan Program SmartPLS 2.0 M3. Semarang: Badan Penerbit Universitas Dipenogoro, 2012.

[16] H. Latan, Model Persamaan Struktural: Teori dan Implementasi AMOS 21.0. Bandung: ALFABETA, 2013.

[17] Sugiyono, Metode Penelitian Kuantitatif. Bandung: ALFABETA, 2018. 